\title{
Lower quality of life in longstanding mild primary hyperparathyroidism
}

\author{
Menor qualidade de vida em hiperparatireoidismo \\ primário crônico leve
}

Andreia Veras', Juliana Maia' ', Patricia Mesquita', Catia Eufrazino', Francisco Bandeira'

\begin{abstract}
Objective: To describe the non-classical manifestations and quality of life in patients with primary hyperparathyroidism (PHPT). Subjects and methods: We evaluated non-classical manifestations and quality of life of 22 patients with PHPT using the SF-36 questionnaire according to the time since diagnosis. Results: In the scores of quality of life, a significant difference was found comparing the groups with previous and recent diagnosis of PHPT in terms of functional capacity $(39+22.83$ vs. $76.25+22.37 ; p=0.001)$, limitation of physical aspects $(30+38.73$ vs. 75 $+21.32 ; p=0.006)$, general health $(57.20+19.16$ vs. $77.75+15.70 ; p=0.012)$, and vitality $(49.00+$ 21.19 vs. $70.00+24.12 ; p=0.044)$. Conclusion: We found a significant difference in quality of life in relation to the time of the diagnosis of PHPT. Arq Bras Endocrinol Metab. 2013;57(2):139-43
\end{abstract}

\section{Keywords}

Primary hyperparathyroidism; non-classical manifestations; quality of life; depression

\section{RESUMO}

Objetivo: Descrever as manifestações não clássicas e a qualidade de vida em pacientes com hiperparatireoidismo primário (HPTP). Sujeitos e métodos: Avaliamos as manifestações não clássicas e a qualidade de vida em 22 pacientes com HPTP por meio do questionário SF-36, segundo o tempo desde o diagnóstico. Resultados: Nos escores de qualidade de vida, foi observada uma diferença significativa na comparação dos grupos com diagnóstico anterior ou recente de HPTP em termos de capacidade funcional $(39+22,83$ vs. $76,25+22,37 ; p=0,001)$, limitação de aspectos físicos $(30+38,73$ vs. $75+21,32 ; p=0,006)$, estado geral de saúde $(57,20+$ $19,16$ vs. $77,75+15,70 ; p=0,012)$ e vitalidade $(49,00+21,19$ vs. $70,00+24,12 ; p=0,044)$. Conclusão: Observamos uma diferença significativa na qualidade de vida em relação ao tempo desde o diagnóstico do HPTP. Arq Bras Endocrinol Metab. 2013;57(2):139-43

Descritores

Hiperparatireoidismo primário; manifestações não clássicas; qualidade de vida; depressão
1 Division of Endocrinology and Diabetes, Agamenon Magalhães Hospital, Brazilian Ministry of Health (MS/SUS), University of Pernambuco (UPE) Medical School, Recife, PE, Brazil Agamenon Magalhães Hospital (MS/SUS/UPE)

\section{Correspondence to: Juliana Maia \\ Division of Endocrinology, Agamenon Magalhães Hospital University of Pernambuco Medical School \\ Estrada do Arraial, 2723 52021-380 - Recife, PE, Brazil maia.juliana@gmail.com}

Received on Sept/12/2012 Accepted on Nov/26/2012

\section{INTRODUCTION}

$\mathrm{I}$ $\mathrm{n}$ the past, primary hyperparathyroidism (PHPT) presented extreme manifestations of excess parathyroid hormone, including marked hypercalcemia, osteitis fibrosa cystica, advanced renal disease, and neuropsychiatric disorders. However, the clinical presentation of hyperparathyroidism has dramatically changed partly due to the introduction of routine calcium serum measurements since 1970. Today, PHPT is more often presented as asymptomatic hypercalcemia (1).
A less common presentation of asymptomatic PHPT is characterized by normal serum calcium levels and high levels of parathyroid hormone (PTH) in the absence of an apparent secondary cause of elevated levels of PTH. This normocalcemic variant may represent an early manifestation of PHPT (2).

Signs and symptoms of hyperparathyroidism largely reflect the effects of hypercalcemia and may involve multiple organs and systems (3). Manifestations of PHPT in non-classical organs have been reported with involvement of the cardiovascular, gastrointes- 
tinal, neuropsychiatric systems, and glucose metabo$\operatorname{lism}(4,5)$.

Gastrointestinal symptoms include constipation, anorexia, nausea, vomiting, and abdominal pain. Pancreatitis and peptic ulcer disease are also associated with hypercalcemia. However, the pathophysiological mechanism of this association remains uncertain $(4,6)$.

Despite the increasing evidence that PHPT may contribute to increased cardiovascular morbidity and mortality, the etiopathogenic mechanisms of this association are still not completely understood. Various abnormalities have been found in conjunction with PHPT, including hypertension, premature atherosclerosis, valve calcification, left ventricular hypertrophy, and arrhythmias $(4,5)$.

The excess PTH secretion seems to be involved in the deterioration of the secretion and sensitivity to insulin, resulting in a high frequency of worsening of glucose tolerance and diabetes mellitus type $2(5,7)$.

Recent descriptions of PHPT include examples of well-defined neurological and psychiatric syndromes, ranging from signs of muscular atrophy to complete psychosis.

However, these manifestations are not a typical presentation of the illness, and reports suggest that many patients with PHPT discover the disease in the course of biochemical screening, and present vague and nonspecific symptoms (fatigue, weakness, lassitude, anxiety, and depression) (4).

Primary hyperparathyroidism is a frequent endocrine disorder in the elderly population (8). As life expectancy is increasing worldwide, the incidence and prevalence of PHPT is likely to continue to increase in this age group. Therefore, it is necessary to conduct further studies on PHPT and quality of life.

\section{SUBJECTS AND METHODS}

The study included patients newly diagnosed with PHPT and patients with previous diagnosis of PHPT who were followed up at our institute, totaling 22 patients.

Primary hyperparathyroidism was defined as hypercalcemia confirmed after two measurements (serum calcium $>10.3 \mathrm{mg} / \mathrm{dL}$, albumin-corrected in the presence of hypoalbuminemia), and intact PTH above $52.5 \mathrm{pg} / \mathrm{mL}$, which corresponds to the $75^{\text {th }}$ percentile after exclusion of severe bone diseases, other causes of hypercalcemia and elevated PTH, such as secondary hyperparathyroidism (chronic renal failure GFR-
$\mathrm{MDRD} \leq 60 \mathrm{~mL} / \mathrm{min} / 1.73 \mathrm{~m}^{2}$, rickets, osteomalacia, and hepatobiliary diseases), benign familial hypercalcemia, cancer, use of thiazide diuretics and lithium $(1,2)$.

The patients were referred to the interviewer and answered a quality of life questionnaire, the Brazilian version of SF-36. The questionnaire contains 36 items, 35 of them grouped into eight dimensions, and a last item that assesses changes in health over time. For each dimension, items are coded, aggregated, and transformed into a scale from zero (worst state of health) to 100 (best state of health).

The non-classical manifestations of PHPT evaluated were: high blood pressure (HBP), diabetes mellitus type 2 (DM2), pancreatitis and peptic ulcer (gastrointestinal disorder - GID), depression and cardiovascular diseases (CVD), such as angina, acute myocardial infarction, and cardiac arrhythmias. The presence of these disorders was assessed by means of medical records and the questionnaire.

The diagnosis of depression was assessed using a questionnaire specific for depression, the Portuguese version of the "Structured Clinical Interview for DSM Disorders" (SCID).

Statistical analysis was performed with age, calcium and PTH levels, and made up a subdivision of Gl for patients with previous diagnosis (10 patients, from whom 7 patients had been diagnosed more than 12 months before, and the other 3 patients had been diagnosed less than 12 months before), and G2, for the group of newly diagnosed patients (12 patients).

All patients signed an informed consent form. This study was approved by the Research Ethics Committee of the Agamenon Magalhães Hospital.

\section{Statistical analysis}

Data analysis was performed obtaining percentages of categorical variables and the mean and standard deviation of numeric variables with Student's $t$ test.

Data were entered in EXCEL spreadsheets, calculated using the SPSS software (Statistical Package for the Social Sciences) version 15, and EPI-INFO version 4.6 for DOS. The margin of error used for statistical decisions was $5.0 \%$.

\section{RESULTS}

The 22 patients analyzed with PHPT had a mean age of 64.05 years \pm 11.61 years (Table 1 ), and $95.5 \%$ were postmenopausal women. 
There were no significant statistical differences between the two groups in the evaluation of non-classical manifestations of PHPT: $81.8 \%(18 / 22)$ were hypertensive, 7 in Gl (patients with previous diagnosis of PHPT) and 11 in G2 (newly diagnosed patients); $36.4 \%(8 / 22)$ were diabetic, 3 in Gl and 5 in G2; $4.5 \%$ $(1 / 22)$ had peptic ulcer in Gl; $22.7 \%(5 / 22)$ had a diagnosis of depression, 3 in G1 and 2 in G2. None of the patients had angina, myocardial infarction, and cardiac arrhythmias.

When G1 was compared with G2, mean age was $67.60 \pm 10.19$ vs. $61.08 \pm 12.30, \mathrm{p}=0.189$; serum calcium $10.84 \pm 1.01$ vs. $10.64+0.39, \mathrm{p}=0.570$; and PTH $112.68 \pm 40.00$ vs. $94.51 \pm 47.47, \mathrm{p}=0.349$.

Average time since the diagnosis in months was $13.7 \pm 5.66$ in Gl patients. Statistical analysis of quality of life scores between G1 and G2 showed a significant difference in functional capacity $(39 \pm 22.83$ vs. 76.25 $\pm 22.37 ; \mathrm{p}=0.001)$, limitation of physical aspects $(30 \pm$ 38.73 vs. $75 \pm 21.32 ; \mathrm{p}=0.006)$, general health $(57.20$ \pm 19.16 vs. $77.75 \pm 15.70 ; \mathrm{p}=0.012)$, and vitality $(49.00 \pm 21.19$ vs. $70.00 \pm 24.12 ; \mathrm{p}=0.044)$.

Regarding pain, social aspects, limitation of emotional aspects, and mental health, there were no statistical significant differences, as shown in table 2 .

\section{DISCUSSION}

In the present study, a high prevalence of hypertension in patients with PHPT was found, and this finding is corroborated by others $(9,10)$. Because of the relatively high incidence of hypertension in patients with PHPT, this possibility should be taken into account in the diagnostic investigation of hypertensive patients (10).

No history of cardiovascular disease among patients with PHPT was detected in our study. However, some studies show an increased cardiovascular risk in PHPT $(11,12)$, as well as increased mortality, and fatal and nonfatal cardiovascular disease (13).

Studies have shown an increased prevalence of diabetes among patients with hyperparathyroidism $(14,15)$. Earlier reports showed a prevalence of diabetes mellitus of about $8 \%$ in PHPT (16). In the present study, a much higher prevalence of diabetes mellitus type 2 was found in patients with PHPT, perhaps because it is not infrequent to find high prevalence of glucose disturbance in patients of the mean age described in this study.
Table 1. Baseline characteristics of the study population

\begin{tabular}{lc}
\hline Variable & $\begin{array}{c}\text { PHPT } \\
\text { (Average } \pm \text { DP) }\end{array}$ \\
\hline Age (years) & $64.05 \pm 11.61$ \\
Serum calcium (mg/dL) & $10.73 \pm 0.73$ \\
Serum PTH $(\mathrm{pg} / \mathrm{mL})$ & $102.77 \pm 44.18$ \\
SF-36 & \\
Functional capacity & $59.32 \pm 29.09$ \\
Physical limitation & $54.55 \pm 37.51$ \\
Pain & $55.25 \pm 25.87$ \\
General state of health & $68.41 \pm 19.90$ \\
Vitality & $60.45 \pm 24.73$ \\
Social aspects & $70.64 \pm 26.27$ \\
Emotional limitations & $68.18 \pm 39.14$ \\
Mental health & $70.00 \pm 21.93$ \\
\hline
\end{tabular}

Table 2. Age, serum calcium, serum PTH, and the scores of quality of life according to a previous diagnosis of primary hyperparathyroidism (PHPT)

\begin{tabular}{|c|c|c|c|}
\hline \multirow[b]{2}{*}{ Variable } & \multicolumn{2}{|c|}{ PHPT } & \multirow[b]{2}{*}{$\mathbf{p}$} \\
\hline & $\begin{array}{c}\text { G1 }(n=10) \\
\text { (Average } \pm \text { DP) }\end{array}$ & $\begin{array}{c}\text { G2 }(n=12) \\
\text { (Average } \pm \text { DP) }\end{array}$ & \\
\hline Age (years) & $67.60 \pm 10.19$ & $61.08 \pm 12.30$ & $p=0.189$ \\
\hline Calcium (mg/dL) & $10.84 \pm 1.01$ & $10.64 \pm 0.39$ & $p=0.570$ \\
\hline PTH (pg/mL) & $112.68 \pm 40.00$ & $94.51 \pm 47.47$ & $p=03.49$ \\
\hline \multicolumn{4}{|l|}{ SF-36 } \\
\hline $\begin{array}{l}\text { Functional } \\
\text { capacity }\end{array}$ & $39.00 \pm 22.83$ & $76.25 \pm 22.37$ & $p=0.001^{*}$ \\
\hline $\begin{array}{l}\text { Physical } \\
\text { limitations }\end{array}$ & $30.00 \pm 38.73$ & $75.00 \pm 21.32$ & $p=0.006^{\star}$ \\
\hline Pain & $50.80 \pm 27.50$ & $58.96 \pm 25.02$ & $p=0.475$ \\
\hline $\begin{array}{l}\text { General state of } \\
\text { health }\end{array}$ & $57.20 \pm 19.16$ & $77.75 \pm 15.70$ & $p=0.012^{*}$ \\
\hline Vitality & $49.00 \pm 21.19$ & $70.00 \pm 24.12$ & $p=0.044^{*}$ \\
\hline Social aspects & $63.75 \pm 25.31$ & $76.39 \pm 26.73$ & $p=0.271$ \\
\hline $\begin{array}{l}\text { Emotional } \\
\text { limitation }\end{array}$ & $63.33 \pm 39.91$ & $72,22 \pm 39.78$ & $p=0.608$ \\
\hline Mental health & $62.40 \pm 22.17$ & $76.33 \pm 20.50$ & $p=0.142$ \\
\hline
\end{tabular}

G1: patients with a previous HPTP diagnosis; G2: patients recently diagnosed with HPTP.

Gardner and cols. found 14 patients with peptic ulcer disease (PUD) and one patient with acute pancreatitis in 100 patients who were analyzed in a retrospective study to determine the frequency of gastrointestinal symptoms in patients with PHPT (17). The incidence of pancreatitis in patients with $\mathrm{PHPT}$ varies from $1.5 \%$ to $12 \%$ (18).

Nowadays, it is more difficult to prove this association because hyperparathyroidism is presented in a mild form due to early detection of cases by means of rou- 
tine measurements of serum calcium. In addition, PUD has become less prevalent after the advent of proton pump inhibitors.

Peptic ulcer disease was present in $4.5 \%$ of patients in this study, a prevalence lower than that found in the literature, but below the expectation of reduction in PUD cases. In relation to pancreatitis, no case was found, possibly because of the small size of the study.

Hypercalcemia related to hyperparathyroidism has been associated with mild neurological alterations, including personality changes and depression (1). This last disorder appears to be the most common neuropsychiatric manifestation of PHPT. The degree of hypercalcemia can be correlated with levels of psychological change, but it does not occur in all cases (19).

In the present study, depression was diagnosed in two times more patients with hyperparathyroidism than reported in the literature, and without correlation with serum calcium levels.

A recent study presented in the Annual San Diego Meeting of the ASBMR, on the prevalence of depression in PHPT and sustained benefit of parathyroidectomy, found that depressive symptoms are more common and severe in patients with PHPT than in those without the disease, and parathyroidectomy resulted in a significant improvement in depression indexes (20).

In the present study, statistical analysis of quality of life scores between the groups of previous (Gl) and new (G2) diagnosis of PHPT showed a significant difference in functional capacity, limitation of physical aspects, general health, and vitality, findings that have not been described in literature so far.

A study assessed the quality of life using the SF-36 questionnaire in 24 patients after parathyroidectomy. Worsening of eight domains was found before surgery compared with the national average, and after 6 months of surgery, there was a statistically significant improvement in 6 of 8 domains (physical and social function, physical and emotional limitations, mental health, and energy) (2l).

However, Bollerslev and cols., in a randomized and controlled trial investigating the effects of parathyroidectomy compared with clinical follow-up of asymptomatic PHPT, found no benefit of surgical treatment on morbidity and quality of life (22).

Data on quality of life and many of the neuropsychiatric symptoms that may be associated with PHPT are difficult to be interpreted because many studies are ret- rospective and susceptible to bias (23). Although these symptoms may be difficult to interpret, there is increasing evidence that patients with non-classic symptoms of PHPT demonstrate measurable improvement after parathyroidectomy $(24,25)$.

The present study has some limitations because it is a small series of cases without a control group and the exposure time to PHPT was evaluated by only taking into account the time of diagnosis. Thus, it is not possible to determine the exact time of onset of this disease. A large longitudinal study with a control group would be necessary to prove it.

In conclusion, a significant difference was found in the domains functional capacity, limitations of physical aspects, general health, and vitality, when the group of newly diagnosed patients with PHPT was evaluated in relation to the group with previous diagnosis. It is important to note that no similar data were found in the literature.

Although serum calcium and PTH levels were not significantly different between the two groups, their levels were higher in the group with previous diagnosis; therefore, the length of exposure to these metabolic changes may have favored poorer quality of life.

We conclude that PHPT has many facets, as evidenced by the controversies in the studies conducted to date. Further research is needed in the area.

Disclosure: no potential conflict of interest relevant to this article was reported.

\section{REFERENCES}

1. Green DE, Epstein S. Parathyroids, bone and mineral metabolism. Curr Opin Endocrinol Diabetes. 2006;13:503-8.

2. Bilezikian JP, Silverberg SJ. Asymptomatic primary hyperparathyroidism. N Engl J Med. 2004;350:1746-51.

3. Farford B, Presutti RJ, Moragham TJ. Nonsurgical management of primary hyperparathyroidism. Mayo Clin Proc. 2007;82(3):351-5.

4. Silverberg SJ. Non-classical target organs in primary hyperparathyroidism. J Bone Min Res. 2003;17(Suppl 2):N117-25.

5. Mihai R, Wass JAH, Sadler GP. Asymptomatic hyperparathyroidism - need for multicentre studies. Clin Endocrinol (Oxf). 2008;68(2):155-64.

6. Oliveira UE, Ohe MN, Santos RO, Cervantes O, Abrahão M, Lazaretti-Castro $M$, et al. Analysis of the diagnostic presentation profile, patathyroidectomy indication and bone mineral density follow-up of Brasilian patients with primary hyperparathyroidism. Braz J Med Biol Res. 2007;40(4):519-26.

7. Procopio M, Borretta G. Derangement of glucose metabolism in hyperparathyroidism. J Endocrinol Invest. 2003;26:1136-42.

8. Kebebew E, Duh OY, Clark OH. Parathyroidectomy for primary hyperparathyroidism in octogenarians and nonagenarians. Arch Surg. 2003;138:867-71.

9. Diamond TW, Botha JR, Wing J, Meyers AM, Kalk WJ. Parathyroid hypertension: a reversible disorder. Arch Intern Med. 1986;146:1709-12. 
10. Ringe JD. Reversible hypertension in primary hyperparathyroidism - pre and postoperative blood pressure in 75 cases. Klin Wochenschr. 1984;62:465-9.

11. Andersson P, Rydberg E, Willenheimer R. Primary hyperparathyroidism and heart disease - review. Eur Heart J. 2004;25:1776-87.

12. Lundgren $E$, Lind $L$, Palmér $M$, Jakobsson $S$, Ljunghall $S$, Rastad J. Increased cardiovascular mortality and normalized serum calcium in patients with mild hypercalcemia followed up for 25 year. Surgery. 2001;130:978-85.

13. Yu N, Donnan PT, Leese GP. A record linkage study of outcomes in patients with mild primary hyperparathyroidism:The Parathyroid Epidemiology and Audit Research Study (PEARS). Clin Endocrinol (Oxf). 2011;75(2):169-76.

14. Cardenas MG, Vigil KJ, Talpos GB, Lee MW, Peterson E, Rao DS. Prevalence of type 2 diabetes mellitus in patients with primary hyperparathyroidism. Endocr Pract. 2008;14(1):69-75.

15. Han D, Trooskin S, Wang X. Prevalence of cardiovascular risk factor in male and female patients with primary hyperparathyroidism. J Endocrinol Invest. 2012;35(6):548-52.

16. Taylor $\mathrm{WH}$. The prevalence of diabetes mellitus in patients with hyperparathyroidism and among their relatives. Diabet Med. 1991;8:683-7.

17. Gardner EC Jr, Hersh T. Primary hyperparathyroidism and the gastrointestinal tract. South Med J. 1981;74(2):197-9.
18. Ebert EC. The parathyroids and the gut. J Clin Gastroenterol. 2010;44(7):479-82.

19. Geffken GR, Ward HE, Staab JP, Carmichael SL, Evans DL. Psychiatric morbidity in endocrine disorders. Psychiatr Clin North Am. 1998;21:473-89.

20. Espiritu R, Kearns A, Douglass KV, et al. Depression in primary hyperparathyroidism: prevalence and sustained benefit of parathyroidectomy. J Bone Miner Res. 2011;26(Suppl. 1):S291 [Abstract].

21. Leong KJ, Sam RC, Garnham AW. Health-related quality of life improvement following surgical treatment of primary hyperparathyroidism in a United Kingdom population. Surgeon. 2010;8(1):5-8.

22. Bollerslev J, Jansson S, Mollerup CL, Nordenström J, Lundgren $\mathrm{E}$, Tørring $\mathrm{O}$, et al. Medical observation, compared with parathyroidectomy, for asymptomatic primary hyperparathyroidism: a prospective, randomized trial. J Clin Endocrinol Metab. 2007;92:1687-92.

23. Conroy S, Moulias S, WassifWS. Primary hyperparathyroidism in the older person. Age Ageing. 2003;32:571-8.

24. Sheldon DG, Lee FT, Neil NJ, Ryan JA Jr. Surgical treatment of hyperparathyroidism improves health-related quality of life. Arch Surg. 2002;137:1022-6.

25. Quiros RM, Alef MJ, Wilhelm SM, Djuricin G, Loviscek K, Prinz RA. Health-related quality of life in hyperparathyroidism measurably improves after parathyroidectomy. Surgery. 2003;134:675-81. 